\title{
Enhancement of Rice Resistance to Bacterial Blight by Overexpressing BrCP3 Gene of Brassica rapa
}

\author{
Marjohn C. Niño ${ }^{1}$, Hye Jung Lee ${ }^{1,2}$, Joonki Kim¹, Sailila E. Abdula ${ }^{1,3}$, Yu-Jin Jung ${ }^{4}$, Kwon-Kyoo Kang ${ }^{4}$, Illsup Nou ${ }^{5}$, \\ Yong-Gu Cho ${ }^{1}$ * \\ ${ }^{1}$ Department of Crop Science, Chungbuk National University, Cheongju 28644, Korea \\ ${ }^{2}$ Current Address, Korea Seed \& Variety Service, Kimchon 39660, Korea \\ ${ }^{3}$ Current Address, Philippine Rice Research Institute-Midsayap, North Cotabato 9410, Philippines \\ ${ }^{4}$ Department of Horticulture, Hankyong National University, Ansung 17579, Korea \\ ${ }^{5}$ Department of Horticulture, Sunchon National University, Sunchon 57922, Korea
}

\begin{abstract}
Brassica rapa cysteine protease $3(\mathrm{BrCP})$ is an endopeptidase member of C1A family (papain-like) and CA clan of cysteine protease. Members of papain-like cysteine protease (CP) have emerged to be key enzymes involved in cell death in response to biotic and environmental stresses. Recent progress of $\mathrm{CP}$ research features its diverse and overlapping role in basal and effector-triggered immunity. This study was carried out to characterize $\mathrm{BrCP} 3$ gene in Chinese cabbage and explore its function in rice - Xanthomonas oryzae pv. oryzae pathosystem. Phylogenetic analysis and BLASTP search of its amino acid sequence to the Arabidopsis Protein TAIR 10 database identified $\mathrm{BrCP} 3$ as the closest ortholog of Arabidopsis RD21a. The full-length cDNA of BrCP3 was cloned and transformed into the genome of japonica rice cv. 'Gopum'. Constitutive overexpression of the transgene is driven by Ubi-1 promoter in pFLCIII vector. Regenerated single copy overexpression rice lines were inoculated with three Xoo Korean isolates. Regulation of rice resistance through cysteine protease activity is evident in the overexpression lines which showed enhanced immunity to three isolates as depicted by reduced lesion length compared with the wild type. Our initial results implicate an interesting biological function of $\mathrm{BrCP} 3$ in rice system that has never been reported before.
\end{abstract}

Keywords Brassica rapa, Cysteine protease 3, BrCP3, Bacterial blight, Rice, Xanthomonas oryzae pv. oryzae

\section{INTRODUCTION}

Plants are known to possess sophisticated mechanisms to perceive pathogen attack and activate innate immune response. A number of studies demonstrate that plants have evolved multiple defense strategies for combating invading pathogens. In some cases, plants utilize proteolytic machinery to halt pathogen invasion. Among them is cysteine protease which activity comprises majority of the proteolytic activities in plants. It shares approximately $30 \%$ of total proteolysis in mature non-senescing organs, and in some cases rises to $90 \%$ in response to stimuli (Grudkowska and Zagdanska 2004). MEROPS database showed that papain-like cysteine proteases (PLCPs) are the most abundant in nature being present in numerous species of bacteria, archea, protozoa, fungi, plants, animals, and viruses (Rawlings et al. 2014). Most members of this clan are pre-proteases containing a signal sequence, an autoinhibitory prodomain, and a mature protease domain (van der Hoorn et al. 2004; Niño et al. 2014). The activity of many proteases also depends on $\mathrm{pH}$, indicative of the compartment where they localize, and on the presence of endogenous protease inhibitors or activators (Beynon and Bond 2000). CA clan is further sub-grouped into families. $\mathrm{C} 1$ family is subdivided into $\mathrm{C} 1 \mathrm{~A}$, an extracytoplasmic PLCPs that possess disulfide bridges and accumulate in the vesicles, vacuole, and apoplast, and the subfamily $\mathrm{C} 1 \mathrm{~B}$ which comprises cytoplasmic PLCPs (subfamily C1B) (Rawlings et al. 2006; Shindo and van der Hoorn 2008). A total of 169 plant

Received November 12, 2015; Revised November 14, 2015; Accepted November 17, 2015; Published November 30, 2015

*Comesponding author Yong-Gu Cho, ygcho@cbnu.ac.kr, Tel: +82-43-261-2514, Fax: +82-43-273-2242 
species were recorded in the MEROPS database to contain CP assigned to this family (Rawlings et al. 2014). Of which, 11 species were shown to contain more than 30 homologues in their genome including Glycine max, rice, Arabidopsis lyrata and Zea mays, among others (Niño et al. 2014). But despite the abundance of cysteine proteases in plants, only a few were reported. In Arabidopsis alone, functions for only a few of the more than 550 peptidases (Rawlings et al. 2014) have been studied genetically (Adam and Clarke 2002; Beers et al. 2004; van der Hoorn et al. 2004).

Reports have been made on papain-like cysteine proteases acting as inhibitory agent against fungus, bacteria, oomycete and nematode such as Rcr3 (Krüger et al. 2002), PIP1 (Tian et al. 2007), RD19 (Bernoux et al. 2008), RD21 (Shindo et al. 2012), C14 (Kaschani et al. 2010) and Cath B (Gilroy et al. 2007). Each has unique participation in the induction of host immunity which is evident in the specific interactions with the effectors, involvement in a specific molecular battlefield, and the resulting immunity threshold (Niño et al. 2014).

In Korea, bacterial blight is an emerging disease causing damage to rice yield and grain quality (Noh et al. 2007). Xanthomonas oryzae pv. oryzae (Xoo), a gram negative bacterium, is the causal pathogen of bacterial leaf blight. It is the most serious bacterial disease of rice in many rice-growing areas around the globe. It invades the host plant either through wounds or hydathodes, multiplies in the epitheme and moves to the xylem vessels where active multiplication occurs (Niño-Liu et al. 2006). What made this pathogen difficult to control is their ability to evolve swiftly as indicated by emergence of various pathotypes and races. Studies using molecular genotyping methods on diversity, distribution of $X$. oryzae pv. oryzae, and the relationship between phylogeny and virulence have provided better information on population structures and their evolution and have indicated that BB pathogen populations from different Asian countries were distinct (Leach et al. 1992; Nelson et al. 1994; Adhikari et al. 1995). The population structure of Korean Xoo races is markedly distinct from Philippines (64\% distance) and Japan (58\% distance). Recent pathotyping results also suggested that Korean isolates had continuous genetic variations; therefore, they might have had unique hierarchical evolutionary pathways for their pathogenicity (Jeung et al. 2006). Korean race $K 1$ showed a decreasing trend by the spread of rice cultivars with $\mathrm{Xa1}$ and $\mathrm{Xa} 3$ genes. However, races $\mathrm{K} 2$ and $\mathrm{K} 3$ have increased in Korea. The new pathotype, K3a that had reaction scores identical to those of race $\mathrm{K} 3$ against Korean differential lines caused severe BB epidemics in 2003 (Noh et al. 2003).

This study was conducted to characterize the cysteine protease $(\mathrm{BrCP} 3)$ in Chinese cabbage, and to clone and overexpress its full-length cDNA into japonica rice to investigate if it plays any role for resistance to Korean $\mathrm{XOO}$ isolates. Our initial findings reveal interesting biological function of the gene in rice-Xoo pathosystem.

\section{MATERIALS AND METHODS}

\section{Isolation of $\mathrm{BrCP} 3$ gene}

The total RNA was extracted from the young leaves of Brassica rapa $c v$. Osome using the Qiagen kit (Qiagen, Korea, Ltd.). About $1 \mu \mathrm{g}$ of high quality RNA was utilized to construct the cDNA library using oligo (dT) primer (Invitrogen, Carlsbad, CA, USA). The cDNA was then used as a template for PCR amplication using $\mathrm{BrCP} 3$ specific primer pair, 5' tagtgaagaaaaatgaagctcc 3' (forward) and 5' gtgtcaccaacttcttacgc 3' (reverse), which were designed from the reference gene LOC103848250. The target gene was amplified using the following condition: denaturation at $95^{\circ} \mathrm{C}$ for $5 \mathrm{~min}, 35$ cycles of $95^{\circ} \mathrm{C}$ for $30 \mathrm{sec}$, $55^{\circ} \mathrm{C}$ for $30 \mathrm{sec}, 72^{\circ} \mathrm{C}$ for $2 \mathrm{~min}$, and a final extension at $72^{\circ} \mathrm{C}$ for $10 \mathrm{~min}$. The PCR product was electrophoresed on $1 \%(w / v)$ agarose gel stained with ethidium bromide. The expected amplicon with the right band size was eluted using the gel purification kit (Bioneer, CA, USA). The purified PCR product was sub-cloned into pGEMT-easy vector (Promega, Madison, USA) and sent to Macrogen Inc. (Macrogen, Seoul, Korea) for sequence analysis. Sequence homology was verified using multiple sequence alignment with hierarchical clustering.

\section{Vector construction and transfomation}

The full-length cDNA of $\mathrm{BrCP} 3$ was ligated at the two 


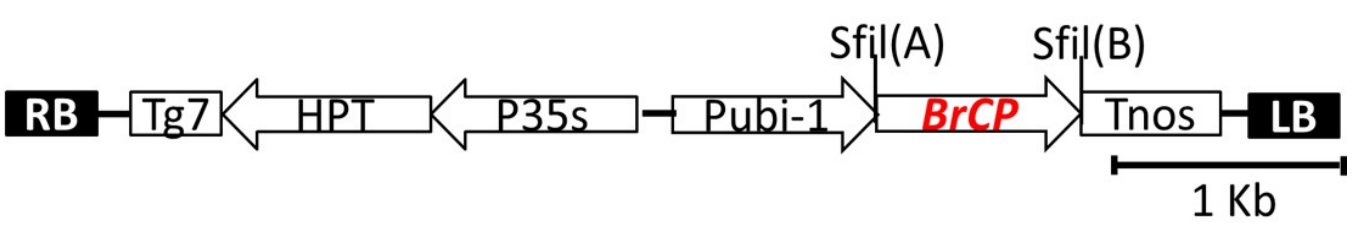

Fig. 1. Schematic diagram of the binary Ti plasmid pFLCIII containing the full-length cDNA of Brassica rapa cysteine protease 3. The vector consists of two different SfiI sites [SfiI(A) and SfiI(B)]. P35S, CaMV 35S promoter; pUbi-1, maize Ubiquitin-1 promoter; $\mathrm{Tg} 7$ and $\mathrm{Tnos}$, polyadenylation signals from gene 7 and nopalin synthase (nos) gene in the T-DNA; hygromycin resistance gene (HPT); LB, left border; RB, right border.

sfiI sites (sfiI A and sfiI B) of pBig_sfiI vector (Takara, Shiga, Japan) (Fig. 1) using the T4 ligase kit (Promega, Madion, USA). Overexpression of this insert gene was constructed under the control of ubiquitin -1 promoter. The binary vector also carries hygromycin phosphotransferase (HPT) gene as a selectable marker (Abdula et al. 2013). The ligated product was transformed into Agrobacterium tumefaciens strain EHA105, which was then cultured on $\mathrm{AB}$ medium containing $50 \mathrm{mg} / \mathrm{L}$ kanamycin sulfate solidified with $1.5 \%$ microagar for three days at $28^{\circ} \mathrm{C}$ in the dark. Agrobacterium culture was harvested and suspended in AAM medium to yield an $\mathrm{OD}_{600}$ of 0.01 . Ten-day-old cultured rice seed calli were immersed in the Agrobacterium suspension by gently inverting the tube for $3 \mathrm{~min}$ and blotted dry. The inoculated calli were placed on 2N6-AS medium solidified with $0.4 \%$ gelrite (Lee et al. 2011).

After three days of co-cultivation at $25^{\circ} \mathrm{C}$ in the dark, calli were washed with sterile distilled water treated with $500 \mathrm{mg} / \mathrm{L}$ carbenicillin. The calli were blotted dry and planted on $2 \mathrm{~N} 6$ medium treated with $50 \mathrm{mg} / \mathrm{L}$ hygromycin and $400 \mathrm{mg} / \mathrm{L}$ carbenicillin under continuous light at $32^{\circ} \mathrm{C}$ for two weeks. Proliferating calli were transferred to MSR medium for shoot and root induction. Regenerated plants were transplanted to soil (a mixture of 50\% composed peat and $50 \%$ earth soil) in the greenhouse and acclimatized for two weeks.

\section{DNA extraction and genomic PCR}

Genomic DNA was extracted as described in Cho et al. (2007) with some modifications. The relative purity and concentration of extracted DNA was estimated using NanoDrop-1000 (NanoDrop Technologies). To verify successful integration of $\mathrm{BrCP} 3$ and hygromycin phosphotransferase (HPT) gene, PCR assay was performed using the Takara ExTaq (Takara, Shiga, Japan) and internal primer sets: 5'GGTCGGATACGGAACAGAGA 3' (forward), 5'GGAGGCGTAACGGGAGAT 3' (reverse) for BrCP3 and 5'GGATTTCGGCTCCAATGTCCTGACGGA3' (forward), 5'CTTCTACACAGCCATCGGTCCAGA3' (reverse) for HPT. The target genes were amplified using the following condition: denaturation at $95^{\circ} \mathrm{C}$ for $5 \mathrm{~min}, 30$ cycles of $95^{\circ} \mathrm{C}$ for $30 \mathrm{sec}, 55^{\circ} \mathrm{C}$ for $30 \mathrm{sec}, 72^{\circ} \mathrm{C}$ for $30 \mathrm{sec}$, and a final extension at $72^{\circ} \mathrm{C}$ for $5 \mathrm{~min}$. The PCR product was electrophoresed on $1 \%(\mathrm{w} / \mathrm{v})$ agarose gel stained with ethidium bromide and viewed under UV light.

\section{TaqMan real-time PCR}

To detect and measure transgene copy number variation within the transgenic rice, TaqMan ${ }^{\mathbb{R}}$ copy number assay was performed using the TaqMan ${ }^{\circledR}$ Reagents (Applied Biosystems, CA USA). The whole process was done based on the TaqMan ${ }^{\mathbb{R}}$ copy number assay protocol. In a copy number quantitation reaction, purified genomic DNA obtained from $\mathrm{T}_{0}$ plants was combined with: TaqMan ${ }^{\circledR}$ Copy Number Assay which contains two primers and a FAM $^{\mathrm{TM}}$ dye-labeled MGB probe to detect the genomic DNA target sequenc; TaqMan ${ }^{\circledR}$ Copy Number Reference Assay which contains two primers and a VIC ${ }^{\circledR}$ dye-labeled TAMRA $^{\mathrm{TM}}$ probe to detect the genomic DNA reference sequence; and TaqMan Genotyping Master Mix which contains AmpliTaq Gold ${ }^{\mathbb{R}}$ DNA polymerase, ultrapure, and dNTPs. The real-time PCR reaction condition was set as follows: enzyme activation at $95^{\circ} \mathrm{C}$ for $10 \mathrm{~min}$, denaturation at $95^{\circ} \mathrm{C}$ for $15 \mathrm{sec}$, and annealing at $60^{\circ} \mathrm{C}$ for $60 \mathrm{sec}$. After amplification, data files were analyzed using Applied Biosystems CopyCaller ${ }^{\mathrm{TM}}$ software for copy 
number quantitation. The number of copies of the target sequence in each test sample is determined by relative quantitation (RQ) using the comparative $\mathrm{C}_{\mathrm{T}}\left(\Delta \Delta \mathrm{C}_{\mathrm{T}}\right)$ method. This method measures the $\mathrm{C}_{\mathrm{T}}$ difference $\left(\Delta \mathrm{C}_{\mathrm{T}}\right)$ between target and reference sequences, then compares the $\Delta \mathrm{C}_{\mathrm{T}}$ values of test samples to a calibrator sample(s) known to have two copies of the target sequence. The copy number is calculated to be two times the relative quantity.

\section{Gene expression analysis}

To characterize the expression of $\mathrm{BrCP} 3$ gene, total RNA were extracted from the different tissues of B. rapa cv. Osome using the RNeasy Mini Kit (Qiagen). Total RNA were cleaned using DNase 1 kit (Invitrogen), and the first-strand cDNA was synthesized using oligo(dT $)_{20}$ primers with SuperScript ${ }^{\mathrm{TM}}$ III Reverse Transcriptase (Invitrogen). BrCP3-specific internal primers were used for quantitative RT-PCR. Actin primers were used as loading controls and also as internal controls to normalize the results of the quantitative RT-PCR reaction.

\section{Bactenial blight screening}

The $T_{2}$ transgenic plants were pre-germinated on trays and transplanted in the pots. Treatment controls were provided including the wild type 'Gopum', susceptible check 'IR24', and resistant check 'IRBB21'. Seedlings were allowed to grow for 45 days in the greenhouse prior to inoculation. Three replications were provided for each treatment with three plants per replication. Bacterial inoculum was prepared from a $48 \mathrm{hr}$-old culture of Xanthomonas oryzae pv. oryzae (Korean isolates K1, K3, $\mathrm{K} 3 \mathrm{a})$ grown on a plated peptone sucrose agar medium. The culture plates were harvested, diluted with sterile distilled water, and the concentration was adjusted to $1 \times 10^{8} \mathrm{cfu} / \mathrm{ml}$. The plants were inoculated by leaf-clipping method and incubated for 14 days. Scoring was done by measuring the lesion length in $\mathrm{cm}$. The average value was interpreted using the standard evaluation system (SES IRRI 1996).

\section{Bacterial growth assay}

Using the same set up mentioned above, sampling was done three days after inoculation. Since K3a is the newest race to develop among the three Xoo races in Korea, only samples from this treatment were used for the assay. About $0.5 \mathrm{~cm}^{2}$ leaf tissue was collected from each treatment plant and immediately washed with $70 \%$ ethanol and $1 \%$ sodium hypochlorite followed by three changes of sterile distilled water. The tissue was macerated aseptically in a $1.5 \mathrm{ml}$ tube containing $100 \mu \mathrm{l}$ sterile distilled water. A serial dilution of $10^{2}, 10^{4}, 10^{6}$ and $10^{8}$ were plated onto peptone sucrose agar medium. The plate was sealed and incubated at $30^{\circ} \mathrm{C}$ for two days. Number of colonies was counted and the number of bacteria (cfu) per milliliter of sample was calculated by dividing the number of colonies by the dilution factor, multiplied by the amount of specimen added to liquified agar.

\section{Field performance evaluation}

The four $T_{3}$ transgenic lines and the wild type were sown in planting trays and kept in greenhouse for three weeks. The seedlings were transplanted in the experimental farm at $30 \times 15 \mathrm{~cm}$ spacing with one seedling per hill. The experiment was laid out in randomized complete block design (RCBD) with five replications. Each transgenic rice line was planted in $2 \times 2 \mathrm{~m}^{2}$ plot size. The fertilizer $\mathrm{N}-\mathrm{P}_{2} \mathrm{O}_{5}-\mathrm{K}_{2} \mathrm{O}$ were applied at the rate of $90-45-47 \mathrm{~kg} / \mathrm{ha}$. The morpho-agronomic characters were evaluated at appropriate growth stages of the transgenic rice (Sun et al. 2011).

Analysis of variance (ANOVA) was computed using the Statistix version 10 . Significant $P$ value was further analyzed using the two-sided Dunnett's multiple comparisons with the wild type as control.

\section{Web-based tool analysis}

The target gene sequence was verified using the BLAST program in NCBI database. Conserved domain was generated by NCBI BLASTN program (http://www.ncbi.nlm.nih.gov/). Sequence alignment and ORF translation were performed using DNAStar's Lasergen sequence (www.dnastar.com).

\section{RESULTS}

\section{Charactenization of $\mathrm{BrCP} 3$ gene}

Analysis of Brassica rapa cysteine protease 3 (BrCP3) 
sequence revealed that it has a full-length cDNA of 1,374 bp with $60 \mathrm{bp}$-long of 5' and $170 \mathrm{bp}$ of 3'UTR which encodes for 457 amino acids (Fig. 2A). Its conserved domain has high affinity to peptidase_C1A subfamily of the clan CA of cysteine protease (Fig. 2B). It contains Cys and His forming a catalytic dyad as catalytic residues. Two other residues play an important role in catalysis: a Gln preceding the catalytic Cys, believed to help in the formation of the oxyanion hole; and an Asn residue which orients the imidazolium ring of the catalytic His (Rawlings and Barrett 1993). It is an endopeptidase containing a signal sequence, a cathepsin propeptide inhibitor domain (I29) in the $\mathrm{N}$ terminus, and a granulin domain in the $\mathrm{C}$ terminus. Members of CA contain proteases with a papain-like fold (van der Hoorn 2008). Papain has specific substrate preferences, primarily for bulky hydrophobic pocket or aromatic residues at the $\mathrm{S} 2$ subsite, a hydrophobic pocket in papain that accommodates the $\mathrm{P} 2$ sidechain of the substrate.
Phylogenetic analysis using deduced amino acid sequences of reported papain-like cysteine proteases in plants showed that $\mathrm{BrCP} 3$ is most closely related to Arabidopsis cysteine protease, RD21A (At1g47128) with $82.49 \%$ homology (Fig. 2C). Further alignment analysis of their conserved domains showed that both are $83.93 \%$ similar in prodomain, $89.25 \%$ in protease domain, and $96.49 \%$ in granulin domain (data not shown).

$\mathrm{RD} 21 \mathrm{~A}$ is highly overexpressed in the leaf of Arabidopsis particularly during senescence indicating its role in cell death (Shindo et al. 2012). Similarly, $B r C P 3$ gene is also remarkably overexpressed in the leaf tissues, about 25 -fold higher than in roots and stems of Brassica rapa although the highest levels, 2.48- and 1.39-fold higher than the leaves, were observed respectively in sepal and stamen (Fig. 3A). Expression in the petal, flower bud, and pistil is also higher compared to roots and stem tissues. Temporal expression analysis also revealed that $\mathrm{BrCP} 3$ is highly
A

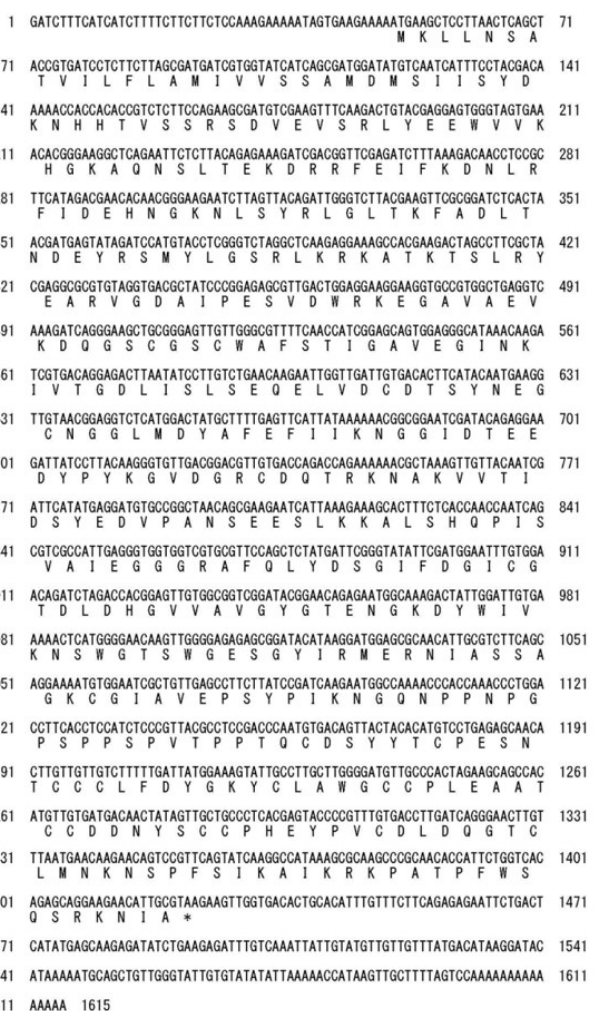

\section{B}

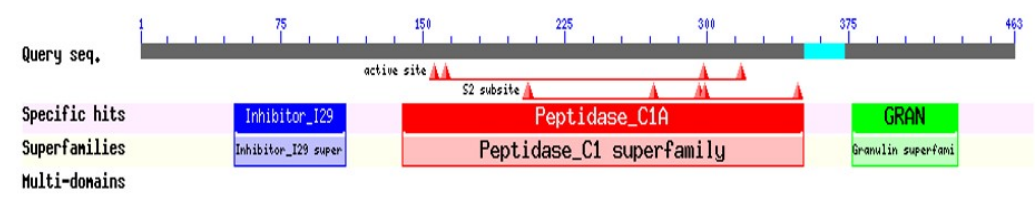

C

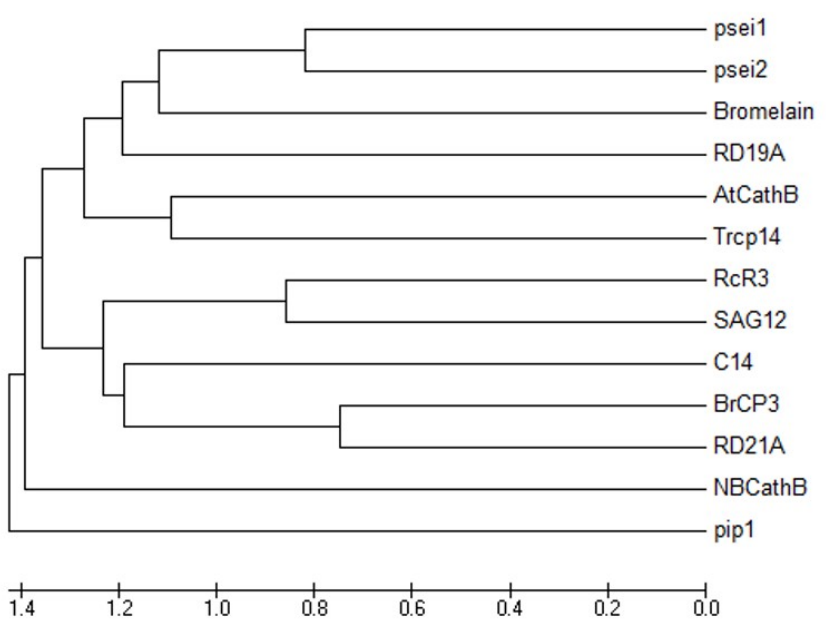

Fig. 2. $B r C P 3$ sequence analysis. (A) Nucleotide and deduced amino acid. (B) Conserved domain structure of $B r C P 3$. (C) Phylogenetic analysis of commonly reported papain-like cysteine protease based on amino acid sequences. 
A

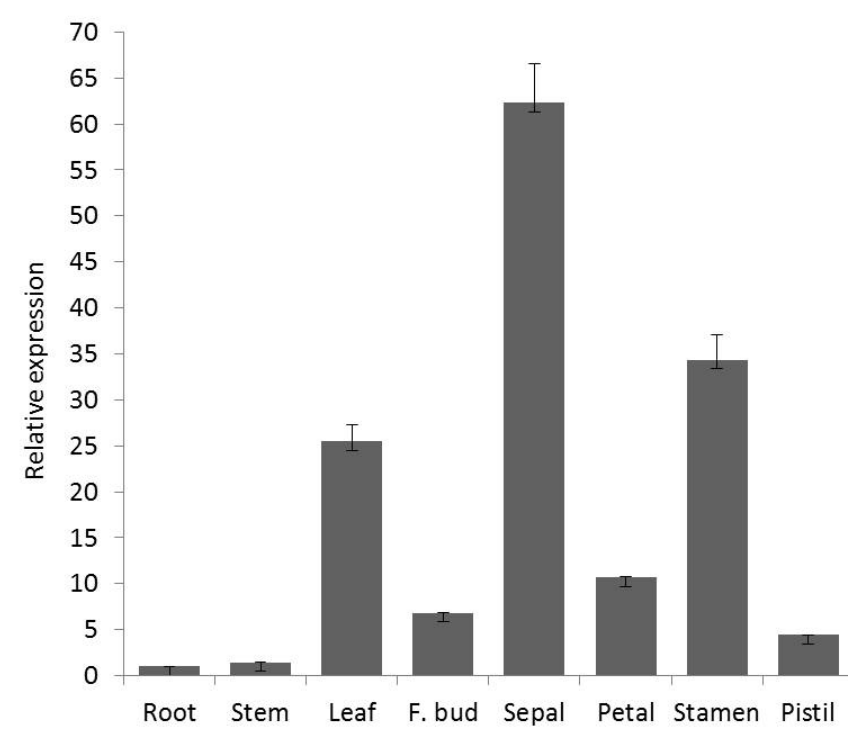

B

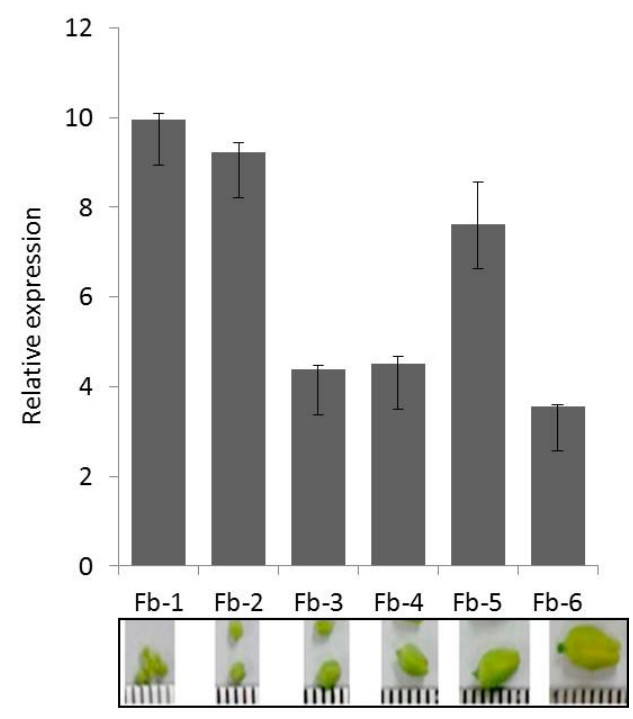

Fig. 3. Transcriptional expression pattern of BrCP3 in the different tissues (A) and flower bud stages (B) of Brassica rapa cv. Osome.

activated at 1 and 2 week-flower bud stages (Fig. 3B). Levels start to decrease at 3 which sustained until 6 weeks.

\section{Development of $\mathrm{BrCP}$-overexpressing transgenic rice}

The $p$ Big_sfiI vector was constructed with the full-length cDNA of BrCP3 along with the HPT gene marker. To facilitate overexpression, integration of the transgenes was constructed under the control of CaMV 35S and ubiquitin-1 promoter and NOS terminator (Abdula et al. 2013). The whole construct was transformed into japonica rice cv. 'Gopum' using Agrobacterium-mediated transformation method, and regeneration of transgenic plants was carried out through tissue culture (Lee et al. 2011). The $\mathrm{T}_{0}$ plants were evaluated for gene copy number using TaqMan copy number assay, a duplex real-time polymerase chain reaction (PCR) which run TaqMan Copy Number Assays simultaneously with a TaqMan Copy Number Reference Assay. The Copy Number Assay detects the target gene and the reference assay detects the positive control sequence that is known to exist in two copies. Of the ten $T_{0}$ plants assayed, four were confirmed to carry single copy of the gene (Fig. 4). These include BCP4 (1.37), BCP6 (0.92), BCP9 (0.96), and BCP10 (1.28). Five plants (BCP1,-2,-3, $-7,-8)$ were found to carry two copies while BCP5 carries 3 .

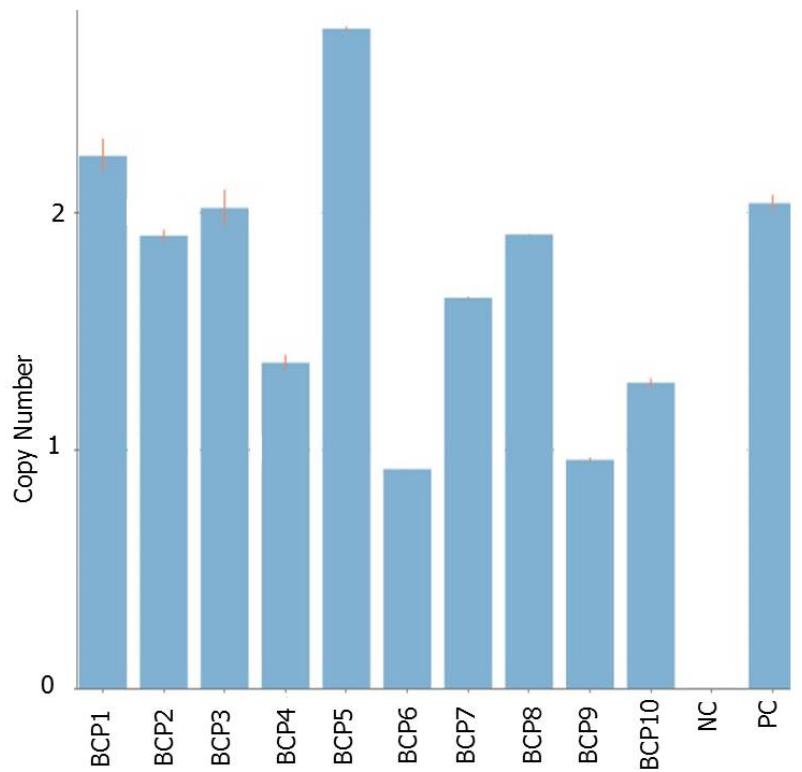

Fig. 4. Copy number of $\mathrm{T}_{0} B r C P 3$ overexpression rice plants assayed using TaqMan real-time PCR.

These single gene copy plants were forwarded to subsequent generations for further analyses. Integration of the transgenes $\mathrm{BrCP} 3$ and $H P T$ was verified in the subsequent generations through genomic PCR (Fig. 5A). Since the transgene was overexpressed under the control of CaMV 35S and ubiquitin-1 promoter, it is important to 
A

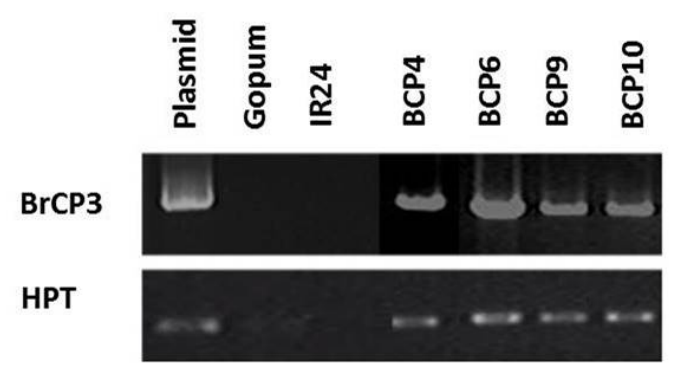

B

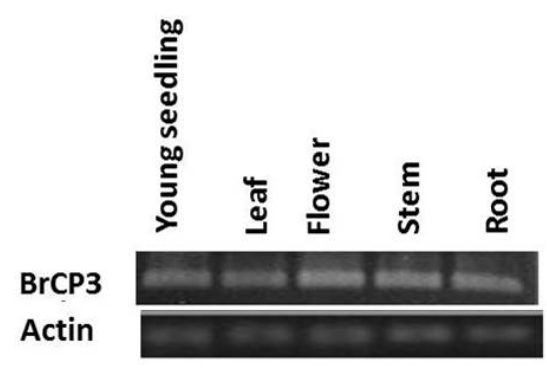

Fig. 5. Molecular characterization of overexpression lines. (A) Genomic PCR assay for the presence of BrCP3 and HPT. (B) Expression of $\mathrm{BrCP} 3$ and actin in the different tissues of transgenic plants.

A

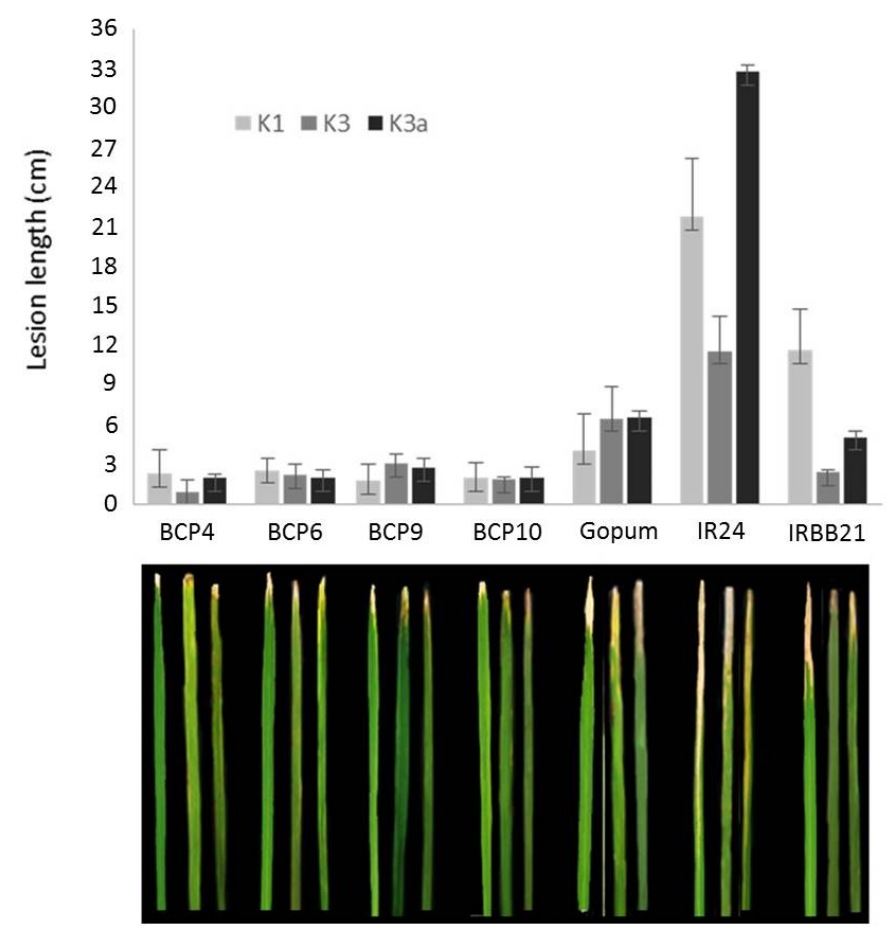

B

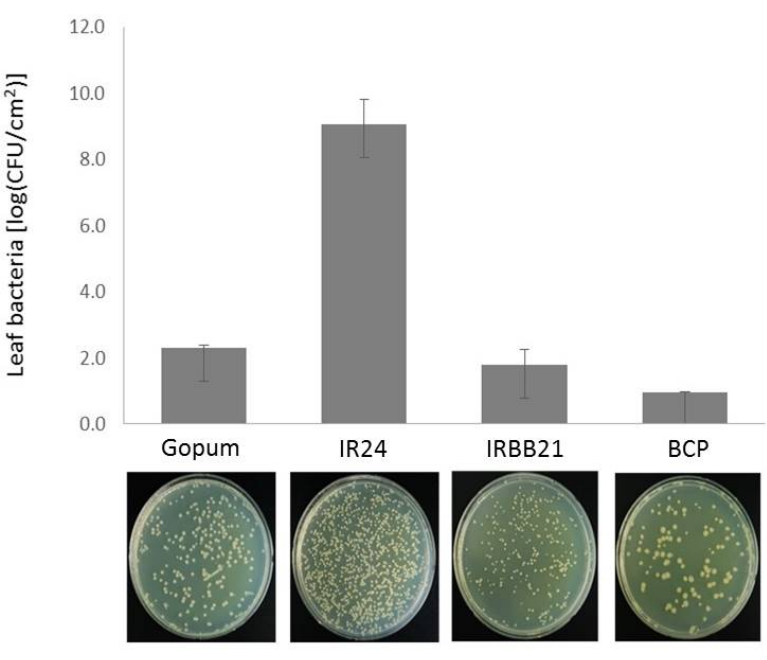

3 days postinoculation

Fig. 6. Evaluation of overexpression lines for resistance to Xoo. (A) Lesion length of bacterial blight infection 14 days after inoculation in the leaves of $\mathrm{BrCP} 3$ transgenic plants, wild type Gopum, susceptible check IR24 and resistant check IRBB21. Three Xoo isolates (K1, K3 and K3a) were used for infection at $1 \times 10^{8} \mathrm{cfu} / \mathrm{ml}$. (B) Bacterial concentration in $0.5 \mathrm{~cm}^{2}$ leaf tissue at $10^{6}$ dilution factor three days after inoculation.

verify if indeed the gene was constitutively overexpressed in the whole parts of the recipient cultivar. RT-PCR assay revealed that $\mathrm{BrCP} 3$ is transcriptionally overexpressed in the whole young seedling, leaf, flower, stem, and root tissues of transgenic rice (Fig. 5B).

\section{$\mathrm{BrCP} 3$ improves resistance to $\mathrm{Xoo}$}

The $\mathrm{BrCP} 3$ transgenic plants showed enhanced resistance to Xoo (Fig. 6A). Lines inoculated with K1 showed lesion length that ranged from 1.8 to $2.6 \mathrm{~cm}$, which are about half shorter than the wild type (4.1). Surprisingly, resistant 
check (IRBB21) also displayed sensitive response similar to the susceptible check (IR24). For K3 treatment, transgenic lines displayed lesions ranging from 0.95 to 3.10 $\mathrm{cm}$ which are shorter than the wild type (6.52) and IR24 (11.62) and relatively similar with the IRBB21 (2.43). For $\mathrm{K} 3 \mathrm{a}$, the transgenic lines had lesions that ranged from 1.2 to $2.8 \mathrm{~cm}$, which are shorter than the wild type (6.6), IRBB21 (5.1) and IR24 (32.8). SES index rating indicates that response of all overexpression lines were categorized as highly resistant (HR) to K1, while they are highly to moderately resistant (MR) both to K3 and K3a. The wild type Gopum which displayed a much longer infection is MR to K1 and moderately susceptible (MS) both to K3 and K3a.

Quantification of leaf bacteria (K3a) revealed that $\mathrm{BrCP} 3$ indeed showed improved resistance (Fig. 6B). Among the dilution factor, number of colonies at $10^{6}$ is the one showing the best count. Colonies at the dilution factor of $10^{2}$ and $10^{4}$ are too many to count while colonies at $10^{8}$ are too few to count. The concentration of bacteria was $0.97 \times 10^{8}$ in $\mathrm{BrCP} 3$ transgenic which is relatively lower than $2.31 \times 10^{8}$ in Gopum, $1.78 \times 10^{8}$ in IRBB21 and $9.05 \times 10^{8}$ in IR24. Data on in vitro and in vivo screening against $X o O$ complemented well supporting our finding that overexpression of $\mathrm{BrCP} 3$ confers resistance to Xoo.

\section{Charactenization of transgenic plants}

The four transgenic lines (BCP4, BCP6, BCP9, BCP10) were evaluated for agronomic characters in the field (Table 1). Data showed that these lines are not significantly different with the wild type Gopum in terms of number of productive tiller, culm length, and panicle length. One line (BCP9), however, is significantly shorter (with $7 \mathrm{~cm}$ difference) than the wild type which is more likely contributed by shorter panicle length displayed by this line.

\section{DISCUSSION}

Brassica rapa cysteine protease 3 ( $\mathrm{BrCP} 3$ ) belongs to the family C1A (papain-like) and clan CA in the Merops protease database. As member of papain-like $\mathrm{CP}$, this gene is synthesized as inactive proenzyme with N-terminal propeptide regions, which are removed upon activation. Residues within its propeptide region play a role in the transport of the proenzyme to lysosomes or acidified vesicles. Sequence homology analysis of its deduced amino acid against selected known plant cysteine proteases revealed its close relationship with Responsive-to-Dessication-21 (RD21A) in Arabidopsis. BLASTP search of its amino acid sequence to the Arabidopsis Protein TAIR 10 database verified that $\mathrm{BrCP} 3$ is the ortholog of Arabidopsis $\mathrm{RD} 21 \mathrm{a}$ (E-value 0.0). Further phylogenetic analysis of the amino acid sequences of the conserved domain showed a very high similarity in prodomain $(83.93 \%)$, protease domain $(89.25 \%)$, and granulin domain $(96.49 \%)$. RD21A is expressed in the key tissues of Arabidopsis including leaf, flower, sepal, stamen, stem, among others. Remarkably, it is highly expressed in the leaf undergoing senescence implying its role in cell death. Similarly, $\mathrm{BrCP} 3$ is also

Table 1. Morphological characteristics of the $T_{3}$ transgenic lines established in the field.

\begin{tabular}{lcccc}
\hline \multicolumn{1}{c}{ Lines } & Productive Tiller & Plant Height $(\mathrm{cm})$ & Culm Length $(\mathrm{cm})$ & Panicle Length $(\mathrm{cm})$ \\
\hline BCP4 & $13.0 \pm 0.83$ & $110.2 \pm 11.72$ & $77.0 \pm 10.58$ & $21.2 \pm 6.23$ \\
BCP5 & $11.4 \pm 0.98$ & $110.5 \pm 6.23$ & $77.0 \pm 8.01$ & $20.9 \pm 2.29$ \\
BCP9 & $12.4 \pm 0.59$ & $106.2 \pm 8.30^{*}$ & $76.9 \pm 7.79$ & $20.3 \pm 6.77$ \\
BCP10 & $11.2 \pm 1.14$ & $109.8 \pm 10.59$ & $77.6 \pm 6.32$ & $21.2 \pm 1.88$ \\
Gopum & $11.8 \pm 0.70$ & $110.4 \pm 14.44$ & $77.2 \pm 12.27$ & $21.0 \pm 9.63$ \\
\hline DMC .05 & 0.15 & 4.79 & 1.98 & 0.03 \\
CV $(\%)$ & 5.69 & 1.01 & 1.14 & 3.33 \\
\hline
\end{tabular}

$\mathrm{DMC}=$ Dunnett's multiple comparison were used to determine the significance (5\% level) of $\mathrm{BrCP} 3$ plants with the wild type Gopum. Asterisk (*) means significant from the wild type at 5\% level. CV=coefficient of variation. Data presented are mean $\pm \mathrm{SE}$. 
highly expressed in sepal, stamen, leaf and flower bud.

The full-length cDNA of $\mathrm{BrCP} 3$, which is 1,374 bp-long, was isolated from the Brassica rapa cv. Osome and integrated into the pBig_sfiI binary vector along with HPT marker. Overexpression of these genes is driven by CaMV $35 \mathrm{~S}$ and ubiquitin-1 promoter to facilitate constitutive expression. The vector construct was transformed into the genome of japonica rice cv. Gopum. Brassica rapa is distantly related to Oryza sativa hence introduction of $\mathrm{BrCP} 3$ has low chances of effecting gene silencing, a phenomenon well-observed in endogenous genes/transgenes in eukaryotes (Kishimoto et al. 2013), which happens when the genes involved share sequence homology in their promoter regions (Matzke et al. 2002; Wassenegger 2002). Four transgenic rice plants overexpressing a single copy of the gene were developed and used for the analyses in this study. Field performance test showed no aberrant morphological characters observed in three transgenic lines (BCP4, BCP5, BCP10) in comparison with the wild type indicating no major genomic changes occurred in the transgenic rice. Induced infection assay of three Xanthomonas oryzae pv. oryzae (Xoo) races (K1, K3, K3a) revealed enhanced immunity to the disease. Although the wild type displays some degree of resistance, where it is moderately resistant to $\mathrm{K} 1$ and moderately susceptible to both $\mathrm{K} 3$ and $\mathrm{K} 3 \mathrm{a}$, lesions were remarkably reduced in all overexpressing lines. The transgenic were highly resistant to $\mathrm{K} 1$ and highly to moderately resistant against $\mathrm{K} 3$ and $\mathrm{K} 3 \mathrm{a}$. To date, at least five races of Xoo have been reported in Korea. The new pathotype K3a was reported to cause severe BB epidemics in 2003 (Noh et al. 2003). Results of our screening test implicate that resistance conferred by cysteine protease to three $\mathrm{Xoo}$ isolates can be employed to regenerate damaged immunity in the host.

Cysteine proteases have emerged as key enzyme involved in the regulation of programmed cell death (PCD) both in animals and plants (Solomon et al. 1999). In plants, PCD has been implicated in xylogenesis (Fukuda 1996; Groove et al. 1997), in senescence, and in the hypersensitive response to pathogens and abiotic stresses (Greenberg 1996; Mitler and Lam 1996; Lamb and Dixon 1997; Solomon et al. 1999). Recent progress of cysteine protease research in plant disease immunity highlights its diverse and overlapping role in basal and effector-triggered immunity. PLCPs are important target of pathogen effector guarded by other R genes for defense (Lozano-Torres et al. 2012). Nucleocytoplasmic trafficking of a few members such as RD19 implies that PCLPs are involved in the crucial transcriptional regulation of defense-related genes in the host (Bernoux et al. 2008). RD21A, the CP ortholog of $\mathrm{BrCP} 3$ in Arabidopsis, exhibits immunity specifically against a necrotrophic fungal pathogen Botrytis cinerea but failed to fend off obligate biotrophic oomycete and Pseudomonas syringae (Shindo et al. 2008). The case, however, is different from our study where $\mathrm{BrCP} 3$ confers resistance to an obligate biotrophic pathogen $\mathrm{Xoo}$. $\mathrm{BrCP} 3$ is just one of the several CPs in Chinese cabbage but to our knowledge, this is the first study conducted exploring its potential function to disease immunity. A detailed understanding on how CP halts Xoo remains to be seen. Nevertheless our initial findings set clues on the probable role of $\mathrm{BrCP} 3$ in the nodes of immunity (perception, signaling, and execution) under rice - Xoo pathosystem.

\section{ACKNOWLEDGEMENTS}

This work was supported by grants from the National Research Foundation (NRF) programs (2014R1A2A1A11052547), the Korean Ministry of Science, ICT and Future Planning, and from the Next-Generation BioGreen 21 Program (PJ01131901), Rural Development Administration, Republic of Korea.

\section{REFERENCES}

Abdula SE, Lee HJ, Jee MG, Jung YJ, Kang KK, Nou IS, Lee SB, Yang WH, Cho YG. 2013. Development and identification of transgenic rice lines with abiotic stress tolerance by using a Full-length Overexpressor gene hunting system. Plant Breed. Biotech 1: 33-48.

Adam Z, Clarke AK. 2002. Cutting edge of chloroplast proteolysis. Trends Plant Sci. 7: 451-456.

Adhikari TB, Vera Cruz CM, Zhang Q, Nelson RJ, Mew TW, Leach JE. 1995. Genetic diversity of Xanthomonas oryzae pv. oryzae in Asia. Appl. Environ. Microbiol. 61: 
966-971.

Beers EP, Jones AM, Dickerman AW. 2004. The S8 serine, C1A cysteine and A1 aspartic protease families in Arabidopsis. Phytochemistry 65: 43-58.

Bernoux M, Timmers T, Jauneau A, Briere C, de Wit PJ, Marco Y, Deslandes L. 2008. RD19, an Arabidopsis cysteine protease required for RRS1-R-mediated resistance, is relocalized to the nucleus by the Ralstonia solanacearum PopP2 effector. Plant Cell 20: 2252-2264.

Beynon R, Bond JS. 2000. Proteolytic Enzymes, Ed 2, Series Practical Approach. Oxford University Press, Oxford.

Cho YG, Kang HJ, Lee JS, Lee YT, Lim SJ, Gauch H, Eun MY, McCouch SR. 2007. Identification of quantitative trait loci in rice for yield, yield components, and agronomic traits across years and locations. Crop Sci. 47: 2403-2417.

Fukuda H. 1996. Xylogenisis: initiation, progression, and cell death. Annu. Rev. Plant Physiol. Plant Mol. Biol. 47: 299-325.

Gilroy EM, Hein I, van der Hoorn RAL, Boevink PC, Venter E, McLellan H, Kaffarnik F, Hrubikova K, Shaw J, Holeva M, Lopez EC, Borras-Hidalgo O, Pritchard L, Loake GJ, Lacomme C, Birch PRJ. 2007. Involvement of Cathepsin B in the plant disease resistance hypersensitive response. Plant J. 52: 1-13.

Greenberg JT. 1996. Programmed cell death: A way of life for plants. Proc. Natl. Acad. Sci. USA 93: 12094-12097.

Groover A, Dewitt N, Heidel A, Jones A. 1997. Programmed cell death of plant tracheary elements differentiating in vitro. Protoplasma 196: 197-211.

Grudkowska M, Zagdanska B. 2004. Multifunctional role of plant cysteine proteinases. Acta Biochim. Pol. 51: 609-624.

Jeung JU, Heu SG, Shin MS, Vera Cruz CM, Jena KK. 2006. Dynamics of Xanthomonas oryzae pv. oryzae populations in Korea and their relationship to known bacterial blight resistance genes. Phytopathology 96: 867-875.

Kaschani F, Shabab M, Bozkurt T, Shindo T, Schornack, Gu C, Ilyas M, Win J, Kamoun S, van der Hoorn RA. 2010. An effector-targeted protease contributes to defense against Phytophthora infestans and is under diversifyingselection in natural hosts. Plant physiol. 154: 1794-804.

Kishimoto N, Nagai J, Kinoshita T, Ueno K, Ohashi Y, Mitsuhara I. 2013. DNA elements reducing transcriptional gene silencing revealed by a novel screening strategy. PLoS One 8: e54670.

Krüger J, Thomas CM, Golstein C, Dixon MS, Smoker M,
Tang S, Mulder L, Jones JDG. 2002. A tomato Cysteine protease required for $\mathrm{Cf}-2$-dependent disease resistance and suppression of autonecrosis. Science 296: 744-747.

Lamb C, Dixon RA. 1997. The oxidative burst in plant disease resistance. Annu. Rev. Plant Physiol. Plant Mol. Biol. 48: 251-275.

Leach JE, Rhoads ML, Vera Cruz CM, White FF, Mew TW, Leung H. 1992. Assessment of genetic diversity and population structure of Xanthomonas oryzae pv. oryzae using a repetitive DNA element. Appl. Environ. Microbiol. 58: 2188-2195.

Lee HJ, Abdula SE, Jee MG, Jang DW, Cho YG. 2011. High-efficiency and Rapid Agrobacterium-mediated genetic transformation method using germinating rice seeds. J Plant Biotechnol 38:251-257

Lozano-Torres JL, Wilbers RHP, Gawronski P, Boshoven JC, Finkers-Tomczak A, Cordewener JHG, Americab AHP, Overmarsa HA, Van 't Kloosterc JW, Baranowskid L, Sobczakd M, Ilyase M, van der Hoorne RAL, Schotsa A, de Wit PGJM, Bakkera J, Goversea A, Smanta G. 2012. Dual disease resistance mediated by the immune receptor Cf-2 in tomato requires a common virulence target of a fungus and a nematode. PNAS doi/10.1073/pnas.1202 867109.

Matzke MA, Aufsatz W, Kanno T, Mette MF, Matzke AJ. 2002. Homology-dependent gene silencing and host defense in plants. Adv. Genet. 46: 235-275.

Mittler R, Lam E. 1996. Sacrifice in the face of foes: Pathogen-induced programmed cell death in plants. Trends Microbiol. 4: 10-15.

Nelson RJ, Baraoidan MR, Vera Cruz CM, Yap IV, Leach JE, Mew TW, Leung H. 1994. Relationship between phylogeny and pathotype for the bacterial blight pathogen of rice. Appl. Environ. Microbiol. 60: 3275-3283.

Niño-Liu D, Ronald PC, Bogdanove AJ. 2006. Xanthomonas oryzae pathovars: model pathogens of a model crop. Mol. Plant Path. 7: 303-324.

Niño M, Kim JK, Lee HJ, Abdula SE, Nou IS, Cho YG. 2014. Key roles of cysteine protease in different plant pathosystem. Plant Breed. Biotech. 2: 97-109.

Noh TH, Lee DK, Kang MH, Shin MS, Na SY. 2003. Identification of new race of Xanthomonas oryzae pv. oryzae (Xoo) in Korea. (Abstr.) Phytopathology 93(suppl.): S66.

Noh TH, Lee DK, Park JC, Shim HK, Choi MY, Kang MH, 
Kim JD. 2007. Effects of bacterial blight occurence on rice yield and grain quality in different rice growth stage. Res. Plant Dis. 13: 20-23.

Rawlings ND, Waller M, Barrett AJ, Bateman A. 2014. MEROPS: the databse of proteolytic enzymes, their substrates and inhibitors. Nucleic Acids Res. 42: D503D509.

Rawlings ND, Barrett AJ. 1993. Evolutionary families of peptidases. Biochem J. 290: 205-218.

Rawlings ND, Morton FR, Barrett AJ. 2006. MEROPS: the peptidase database. Nucleic Acids Res. 34: 270-272.

Solomon M, Belenghi B, Delledonne M, Menachem E, Levine A. 1999. The involvement of cysteine proteases and protease inhibitor genes in the regulation of programmed cell death in plants. Plant Cell 11: 431-443.

Shindo T, Misas-Villamil JC, Horger AC, Song J, van der Hoorn RAL. 2012. A role in immunity for Arabidopsis cysteine protease RD21, the ortholog of the tomato immune protease C14. PLoS ONE 7: e29317. doi:10. 1371/journal.pone.0029317.

Shindo T, van der Hoorn RAL. 2008. Papain-like cysteine proteases: key players at molecular battlefields employed by both plants and their invaders. Mol. Plant Pathol. 9: 119-125.

Sun MM, Abdula SE, Lee HJ, Cho YC, Han LZ, Koh HJ, Cho YG. 2011. Molecular aspect of good eating quality formation in Japonica rice. PloS one 6:e18385 doi:10.1371/journal.pone.0018385

Tian M, Win J, Song J, van der Hoorn RAL, van der Knaap E, Kamoun S. 2007. A Phytophthora infestans cystatin-like protein targets a novel tomato papain-like apoplastic protease. Plant Physiol. 143: 364-377.

van der Hoorn RAL. 2008. Plant proteases: From phenotypes to molecular mechanisms. Annu. Rev. Plant Biol. 59: 191-223.

van der Hoorn RAL, Leeuwenburgh MA, Bogyo M, Joosten MHAJ, Peck SC. 2004. Activity profiling of papain-like cysteine proteases in plants. Plant physiol. 135: 11701178.

Wassenegger M. 2002. Gene silencing. Int. Rev. Cytol. 219: 61-11. 